\title{
Lietuvos baltnugarių ir Lietuvos šèmųjų veislių karvių produktyvumo ir pieno sudèties statistiniai genetiniai tyrimai
}

\author{
Lina Anskienè ${ }^{1}$, \\ Vida Juozaitien $\dot{e}^{1}$, \\ Vilius Žiogas²,

Aleksandras Muzikevičius ${ }^{1}$,
Arūnas Šileika ${ }^{1}$
${ }^{1}$ Lietuvos sveikatos mokslų universiteto
Veterinarijos akademija,
Tilžés g. 18, LT-47181 Kaunas
${ }^{2}$ Lietuvos juodmargiu galviju
gerintojų asociacija,
Trakènug. 14, LT-68115 Trakiškių k.,
Marijampolés sav.
El. paštas: ansiene@lva.lt

Tyrimo tikslas - ịvertinti Lietuvos baltnugarių ir Lietuvos šèmųjų galvijų genealoginę struktūrą, karvių produktyvumą ir pieno sudètị pagal bulių linijas ir bulius, šių požymių selekcinius parametrus, nustatyti bulių veislinę vertę tiesinio prognozavimo BLUP metodu.

Genetiniams tyrimams naudoti 711 Lietuvos baltnugarių ir 808 Lietuvos šèmųjų populiacijos karvių kilmės ir produktyvumo duomenys. Statistinė duomenų analizė atlikta programomis PEST (Groeneveld, 1998) ir VCE (Groeneveld, 1998), SPSS statistiniu paketu (versija 15, SPSS Inc, Chicago, IL). Lietuvos baltnugarès karvės priklausė Olandijos juodmargių veislès $(48,41 \%)$, holšteinų veislès buliu (29,30\%) ir kitoms linijoms bei giminingoms grupèms (22,29\%); Lietuvos šèmosios karvès - holšteinų veislès (52,44 \%) ir kitoms bulių linijoms bei giminingoms grupèms (47,56\%). Abiejų veislių karvių fenotipinė pieningumo koreliacija su pieno riebalų ir baltymų produkcija buvo itin teigiama ( $\mathrm{p}<0,01$ ). Nustatyti pieningumo paveldimumo koeficientai - nuo 0,34 iki 0,53, pieno riebalų - 0,36-0,52, pieno baltymų - 0,38-0,51 - rodo pakankamą efektyviai selekcijai genetinị požymių kintamumą. Nors vietinių veislių bulių veislinès vertès, nustatytos BLUP metodu, indeksai yra $<100$, vietiniai baltnugariai ir šèmieji galvijai yra svarbūs mūsų šalies gyvulininkystès raidai, juos reikia ne tik išsaugoti dèl unikalių fenotipinių ir genetinių savybių, bet ir kryptingai gerinti pagal produktyvumą ir pieno sudètį, formuoti ir plèsti veislių genealoginę struktūrą.

Raktažodžiai: Lietuvos baltnugariai, Lietuvos šèmieji, bulius, paveldimumo koeficientas, veislinès vertès indeksas

\section{IVADAS}

Vietinès galvijų veislès yra svarbios istoriniu, kultūriniu požiūriu, jos gerai prisitaikiusios prie vietos sąlygų, turi unikalių fenotipinių ir genetinių savybių, susiformavusių evoliucijos ir filogenezès raidoje (Malevičiūtè, 2002; Värv, 2004). Lietuvos šèmųjų ir baltnugarių galvijų veislès žinomos nuo XVI a. Iki mūsų dienų jos išlaikè būdingas ūkines savybes, todèl daugelio galvijų augintojų yra teigiamai vertinamos dèl gero prisitaikymo ir nereiklumo aplinkos sąlygų pokyčiams, sveikatingumo, ramaus būdo, gyvybingumo (Šveistienè, Anskienè, 2011).
Ilgą laiką pieninių galvijų selekcijos programos pasaulyje buvo orientuotos ị intensyvų galvijų produktyvumo didinimą panaudojant gerą veislinę vertę turinčius bulius, o tai lemè spartų vietinių galvijų veislių mažejimą (Juškienė, 2003; Grigaliūnaitè, 2004; Bondesan, Veneto, 2011). Lietuvos baltnugariai bei šèmieji galvijai buvo gerinami ivvairių juodmargių bei žalmargių veislių buliais (Šveistienè, Anskienè, 2011).

Pieninių galvijų savybių genetinę pažangą daugiausia lemia efektyvus kiekvienos kartos geriausių bulių panaudojimas (Powell, 2003).

Tyrimo tikslas. Ivertinti Lietuvos baltnugariu ir Lietuvos šèmųjų galvijų genealoginę struktūrą, 
karvių produktyvumą ir pieno sudèti pagal bulių linijas ir bulius, šių požymių selekcinius parametrus. Pirmą kartą Lietuvoje tiesinio prognozavimo BLUP metodu ivertinta Lietuvos baltnugariu ir Lietuvos šèmųjų galvijų veislinè verté, nustatyti ir išanalizuoti bulių veislinès vertès indeksai.

Tyrimu metodai ir salygos. Tyrimai atlikti pagal Valstybinès įmonès „Žemès ūkio informacijos ir kaimo verslo centras“ (ŽŪIKVC), UAB „Gyvulių produktyvumo kontrole““ ir Lietuvos juodmargiu galvijų gerintojų asociacijos duomenis.

Fenotipiniuose tyrimuose analizavome 354 Lietuvos baltnugarių ir 399 Lietuvos šèmųjų karvių 305 dienų laktacijos pieno produktyvumo ir sudèties rodiklius.

Genetiniams tyrimams naudoti 711 Lietuvos baltnugarių ir 808 Lietuvos šemųju populiacijos karvių kilmès ir produktyvumo duomenys.

Statistinè duomenų analizè atlikta programomis PEST (Groeneveld, 1998) ir VCE (Groeneveld, 1998), SPSS statistiniu paketu (versija 15, SPSS Inc, Chicago, IL). Ivertinti tirtų rodiklių aritmetiniai vidurkiai $(\bar{X})$, ju paklaidos $\left(m_{x}\right)$, variacijos koeficientai $(C v)$, koreliacija $(r)$, paveldimumo koeficientai $\left(h^{2}\right)$.

Buliai genetiškai ịvertinti BLUP metodu (Lietuvos Respublikos žemès ūkio ministro $2010 \mathrm{~m}$. gruodžio 20 d. įsakymo Nr. 3D-1096 redakcija):

$$
y=X b+Z a+e
$$

$y$ - požymio fenotipinių reikšmių stebejjimų vektorius; $b$ - fiksuotų efektų vektorius; $a$ - atsitiktinių efektų vektorius (adityvinis genetinis efektas); $e$ - paklaidų vektorius; $X$ ir $Z$ - duomenų dažnio matricos, kurios atitinkamai susieja nekintamus ir genetinius efektus. Genetinių veiksnių vertinimui naudojome BLUP metodo "gyvulio“ modeli su giminystès ryšiu matrica.

Lietuvos baltnugariai ir šèmieji galvijai ị bulių linijas suskirstyti pagal tiesioginę tèvinę kilmès pusę prisilaikant galiojančio bulių linijų ir giminingu grupių klasifikatoriaus (99 - kitos linijos ir giminingos grupess; 190 - Olandijos juodmargių bulių linijos ir giminingos grupes; 920 - kiti holšteinų veislès buliaus W. A. Burke Lad 697789 palikuonys, 931 - Wis Ideal 933122 Round. Oak Rag. Apple Elevation, 932 - Astronaut 1458744 gimininga grupè, 951 L. Fond Hope 1243697 linija, 980 - kiti ABC R Sovereign 198998 palikuonys) (GVIS).

\section{TYRIMŲ REZULTATAI IR APTARIMAS}

Ištyrę Lietuvos baltnugarių kontroliuojamų karvių genealogiją, nustateme, kad 48,41 \% Lietuvos baltnugarių karvių priklause Olandijos juodmargių bulių linijoms ir giminingoms grupems (kodas - 190). Joms priskiriamos bulių Bukio LJ4326 ir Braižo LJ4387 pirmos kartos moteriškos giminès palikuonys. Kitoms linijoms ir giminingoms grupėms (kodas - 99) priklausė 22,29 \% karvių, buliaus Baltnugario LJ4329 moteriškos giminès palikuonių. Holšteinų veislès buliaus Astronaut 1458744 giminingai grupei (kodas - 932) priskyrème 14,01 \% baltnugarių karvių, buliaus Mènulio LJ4353 moteriškos giminès palikuonių. Šios veislès buliaus W. A. Burke Lad 697789 palikuonims (kodas - 920) pagal tiesioginę tèvinę kilmès pusę priskyrème 10,83 \% karvių, buliaus Taško LJ4403 palikuonių. Analizè parodè, kad holšteinų genotipo Wis Ideal 933122 Round. Oak Rag. Apple Elevation buliaus linijai (kodas - 931) priklausė 4,46 \% karvių, buliaus Rolo LJ4427 palikuonių.

Lietuvos šèmųjų karvių pasiskirstymo pagal bulių linijas tyrimas parodé, kad 47,56 \% karvių yra kitų linijų ir giminingų grupių (klasifikatoriuje žymimų kodu 99). Tai bulių Šèmio LJ4483, Laido LJ4351, Šamo LJ4347, Šèmio LJ4363, Tauro LJ4362 moteriškos giminès palikuonys. Holšteinu veislès buliaus Astronaut 1458744 giminingai grupei (kodas - 932) priklausè 20,74 \% karvių, buliu Elisono LJ4519, Elito LJ4361 moteriškos giminès palikuonių. Buliaus L. Fond Hope 1243697 linijai (kodas - 951) priskyrème 15,85 \% tirtų karvių, buliaus Princo LJ4330 moteriškos giminès palikuonių. Kitiems holšteinų buliaus ABC R Sovereign 198998 palikuonims (kodas - 980) priklausè 15,85 \% karvių, buliaus Riešutèlio LJ4402, Rolio LJ4517 palikuonių.

Karvių pieno kiekis, riebumas ir baltymingumas ekonomiškai yra svarbiausios pieniniu galvijų savybės daugelių veislių selekcijos programose (Klaas, Enevoldsen, Ersbøll, Tölle, 2005).

Daugelio tyrejų (Jukna, Pauliukas, 2001) duomenimis, holšteinų veislès buliai karvių pieningumą padidina $10-45 \%$.

Statistiniai tyrimai, pateikti 1 pav., parodè, kad pieningiausios baltnugarès karvès buvo holšteinų veislès buliaus Wis Ideal 933122 Round. Oak Rag. Apple Elevation linijos $(5976 \pm 633 \mathrm{~kg})$, o 


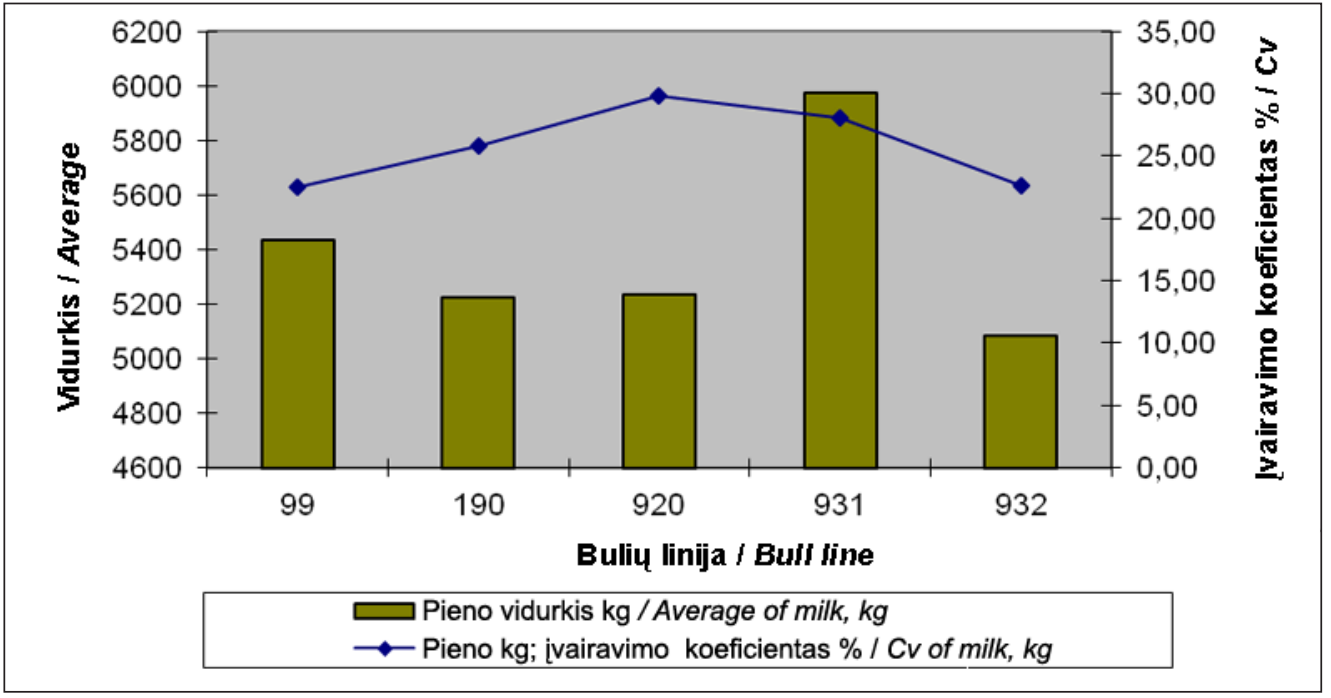

1 pav. Lietuvos baltnugarių karvių pieningumas pagal bulių linijas

Fig. 1. Lithuanian White-backed cows' milk, kg by bull lines

mažiausiai pieningos - kito holšteinų veislès buliaus - Astronaut 1458744 giminingos grupès karvès $(5084 \pm 246 \mathrm{~kg})$.

M. J. Auldist su grupe tyrejjų (1996), E. Urech ir kiti mokslininkai (1999) nustatè, kad baltymų kieki piene labiausiai lemia genetinès karviu savybès (holšteinų genai).

Geriausia pieno sudetis pagal riebumo ir baltymingumo sumą \% (2 pav.) buvo kitų holšteinų veislès buliaus W. A. Burke Lad 697789 palikuonių (kodas 920) Lietuvos baltnugarių karvių (pieno riebumo vidutiniškai $4,59 \pm 0,15 \%$ ir 3,35 $\pm 0,06 \%$ baltymingumo). Mažiausias pieno riebumas $(4,045 \pm 0,12 \%)$ nustatytas holšteinų veislès buliaus Astronaut 1458744 giminingos grupès karvių, mažiausias baltymingumas $(3,14 \pm 0,05 \%)$ - Wis Ideal 933122 Round. Oak Rag Apple Elevation linijos palikuonių (kodas 931) ( $\mathrm{p}<0,001)$.

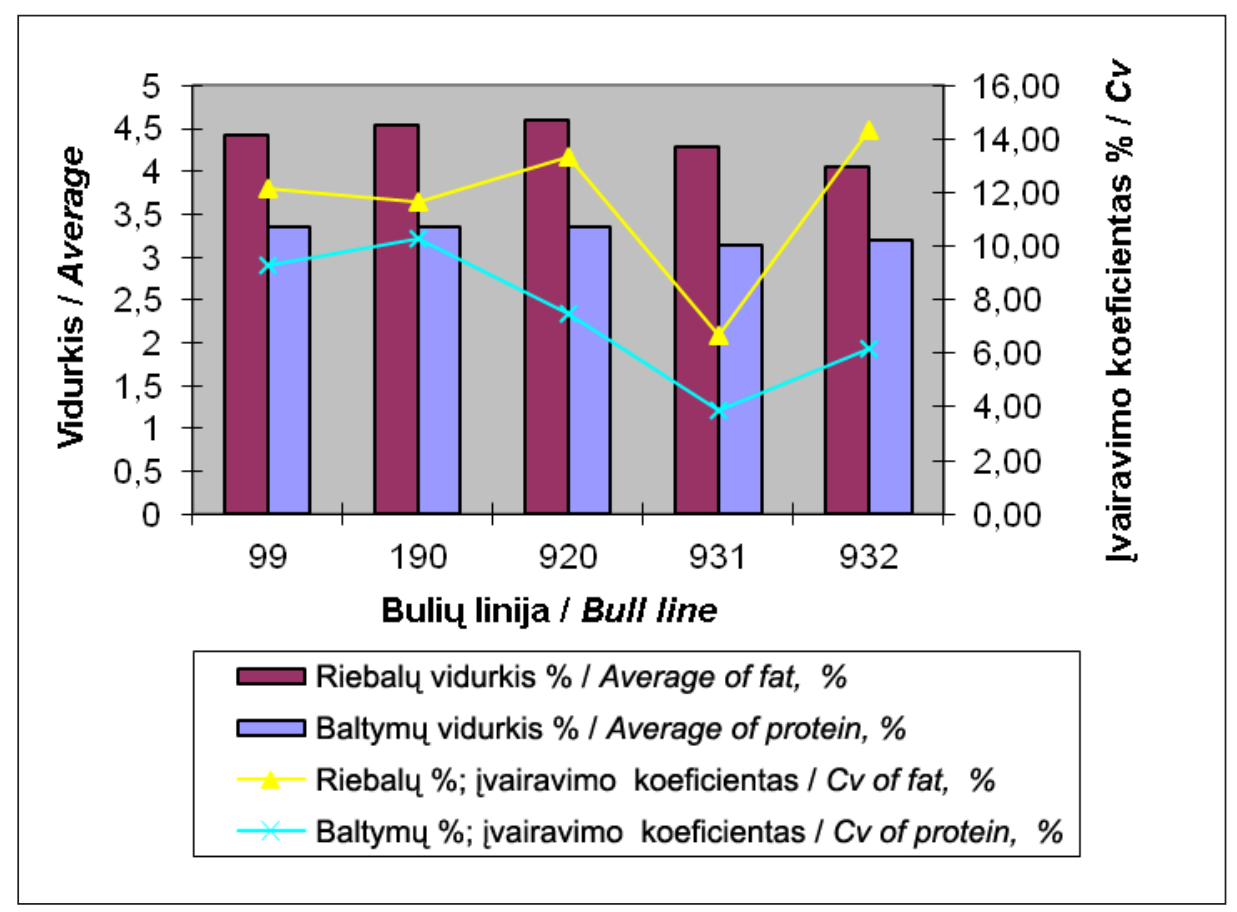

2 pav. Lietuvos baltnugarių karvių pieno sudètis pagal bulių linijas

Fig. 2. Lithuanian White-backed cows' milk composition by bull lines 
Lietuvos šèmųjų karvių produktyvumo analizė pagal bulių linijas (3 pav.) atskleidè, kad pieningiausios $(6108 \pm 216 \mathrm{~kg})$ buvo holšteinų veislès buliaus L. Fond Hope 1243697 moteriškos giminès palikuonys, o mažiausiai pieningos $(5279 \pm 240 \mathrm{~kg})$ - taip pat holšteinų veislès bu- liaus Astronaut 1458744 giminingos grupès karvès $(\mathrm{p}<0,01)$.

Geriausia pieno sudètis pagal riebumo ir baltymingumo sumą \% (4 pav.) buvo Lietuvos šemųjų karvių - kitų holšteinų veislès buliaus ABC R Sovereign 198998 palikuonių (pieno vidutiniškai

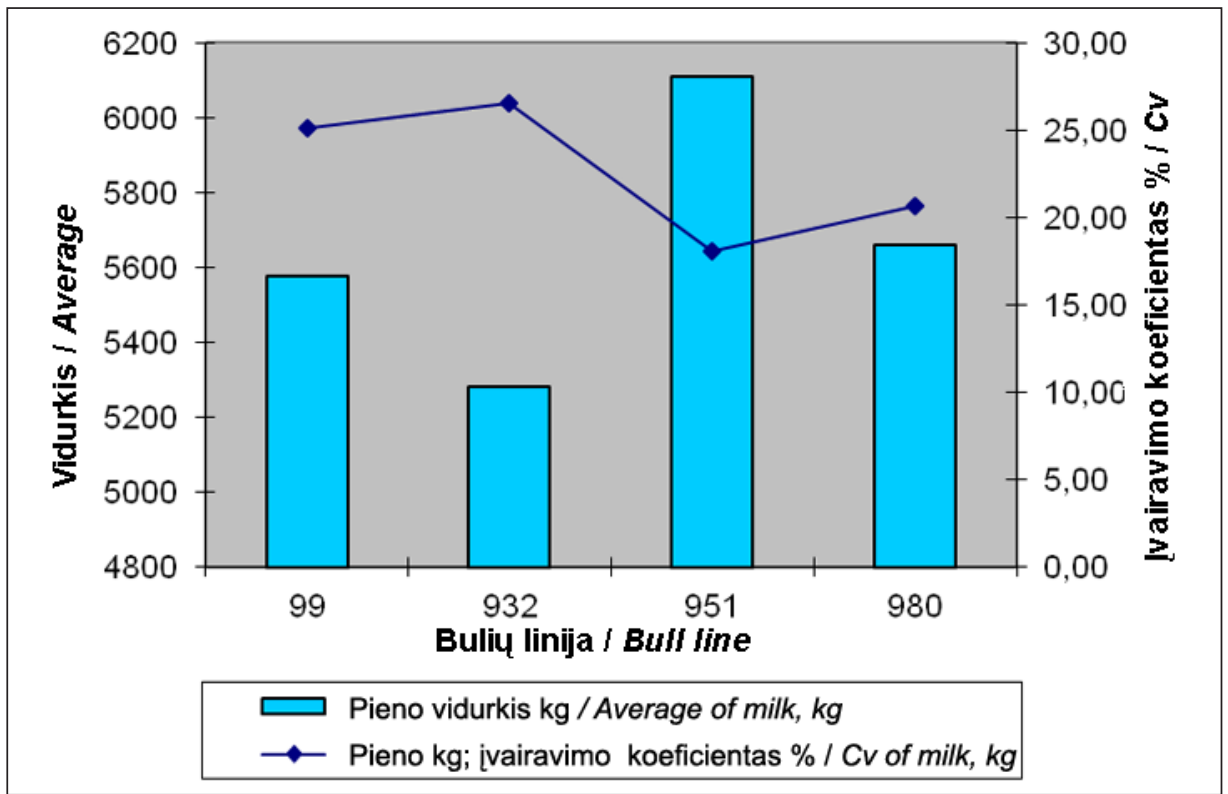

3 pav. Lietuvos šèmujų karvių pieningumas pagal bulių linijas

Fig. 3. Lithuanian Ash-grey cows' milk, $\mathrm{kg}$ by bull lines

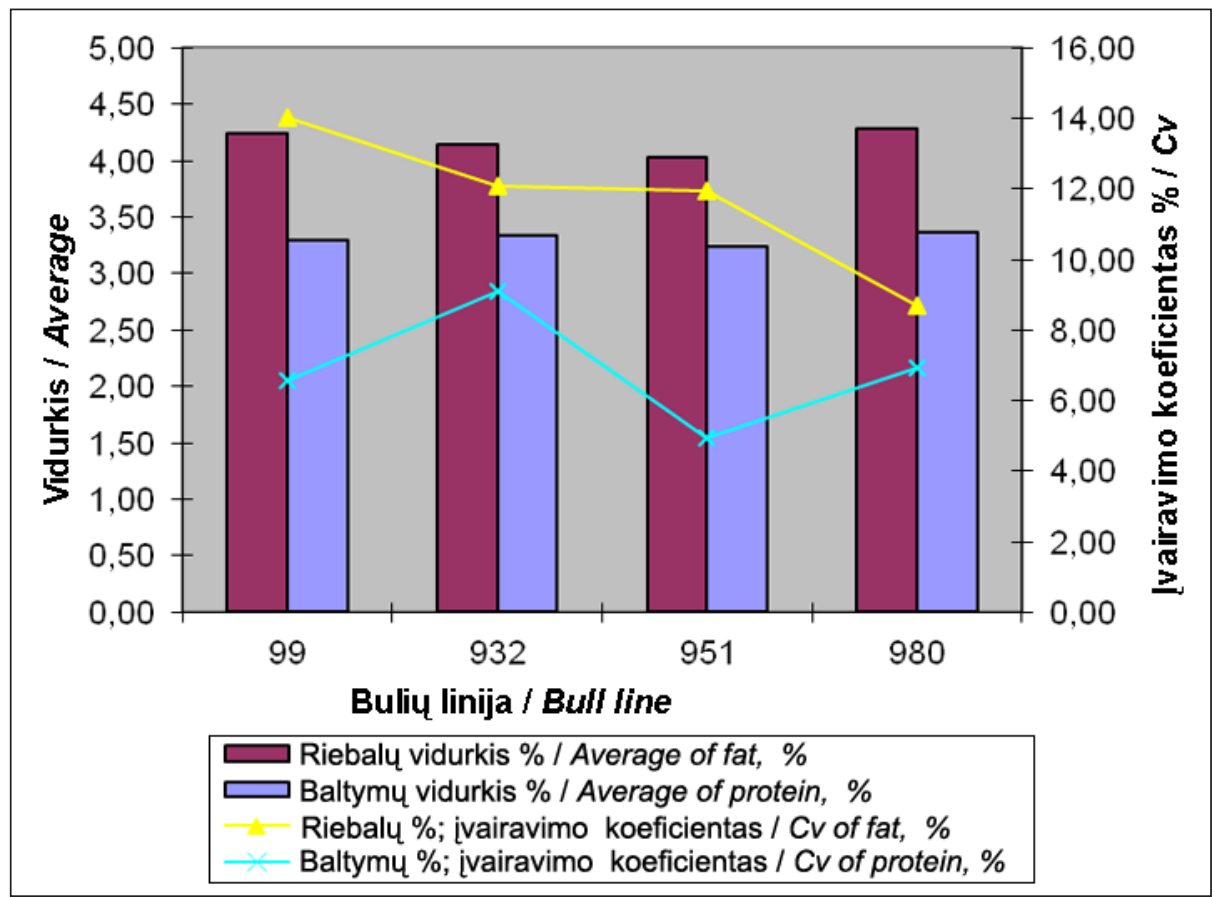

4 pav. Lietuvos šèmujų karvių pieno sudètis pagal bulių linijas

Fig. 4. Lithuanian Ash-grey cows' milk composition by bull lines 
$4,29 \pm 0,07 \%$ riebumo ir $3,36 \pm 0,04 \%$ baltymingumo), prasčiausia pieno sudètis - holšteinų veislès buliaus L. Fond Hope 1243697 karvių $(4,03 \pm 0,094 \%$ riebumo ir $3,23 \pm 0,031 \%$ baltymingumo, $\mathrm{p}<0,001)$.
Nustatėme (5, 6 pav.), kad produktyviausių Lietuvos baltnugarių karvių tèvai pagal palikuonių pieningumą buvo bulius Rolas LJ4427 $(5976 \pm 633 \mathrm{~kg})$, pagal pieno riebumą - bulius Taškas LJ4403 (4,59 \pm 0,149 \%), pagal

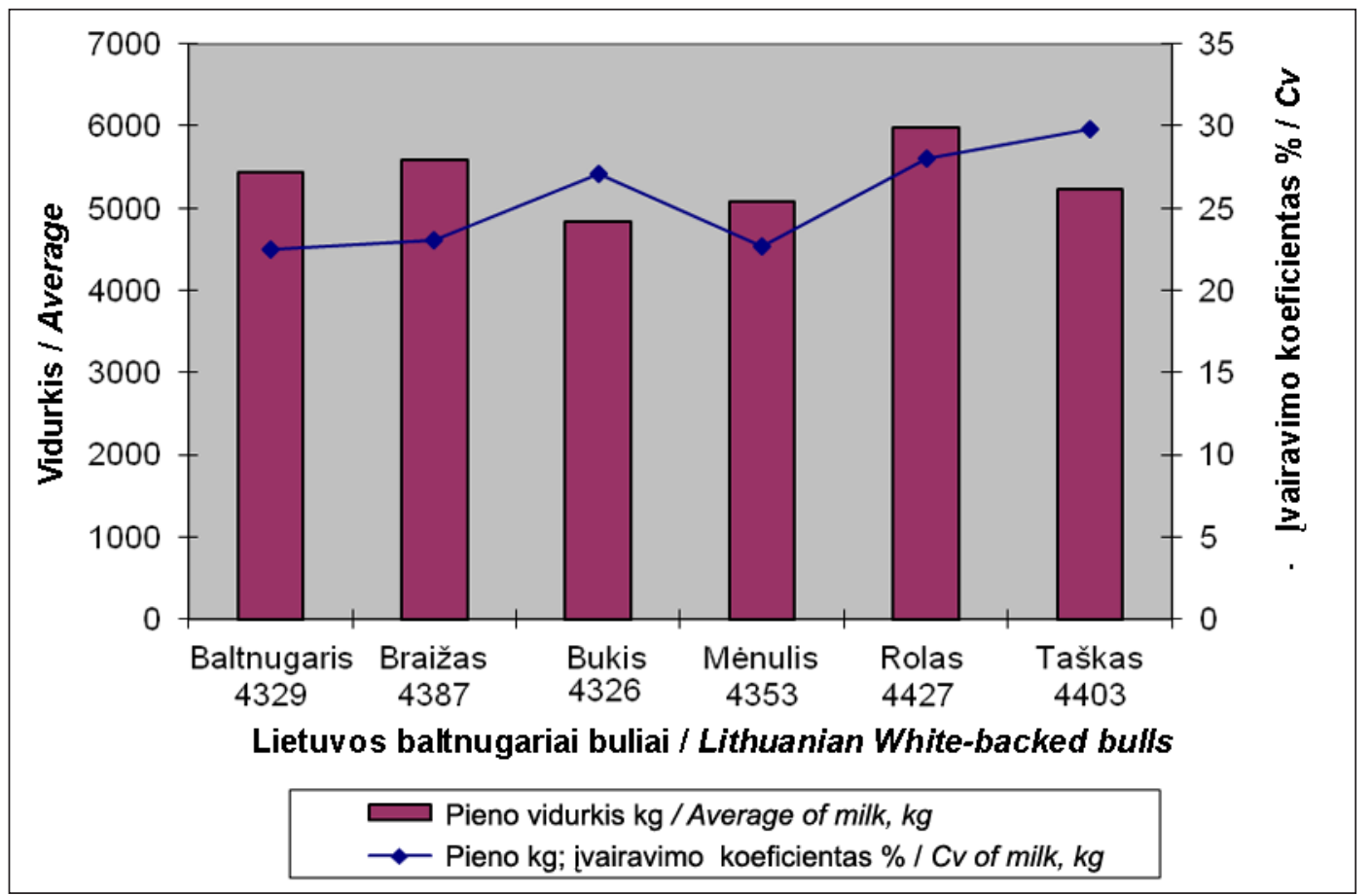

5 pav. Lietuvos baltnugarių karvių pieningumas pagal bulius

Fig. 5. Lithuanian White-backed cows' milk, $\mathrm{kg}$ by bulls

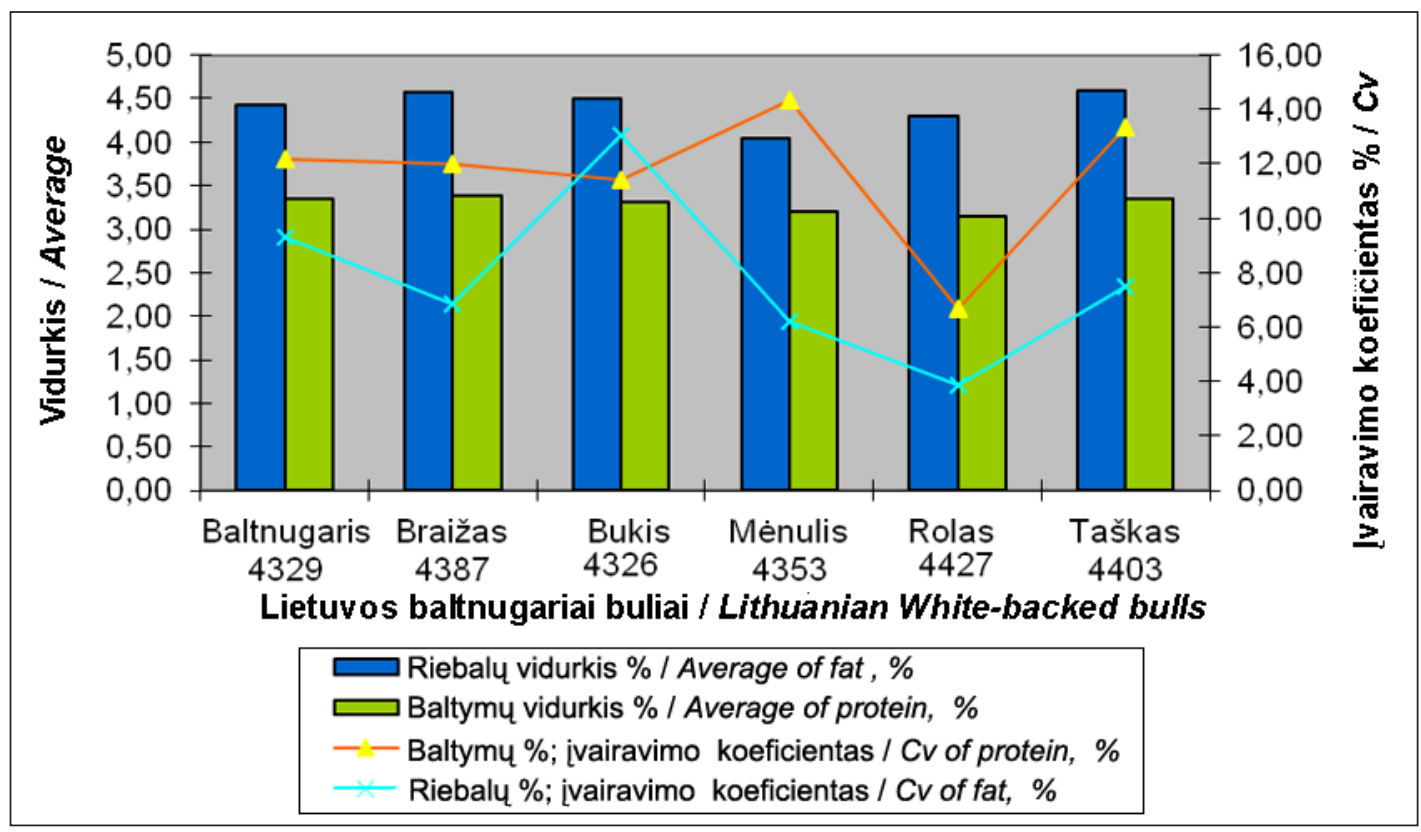

6 pav. Lietuvos baltnugarių karvių pieno sudètis pagal bulius

Fig. 6. Lithuanian White-backed cows' milk composition by bulls 
pieno baltymingumą - bulius Braižas LJ4387 $(3,38 \pm 0,037 \%)$.

7 ir 8 pav. pateikti duomenys parodo, kad pieningiausių $(6108 \pm 216 \mathrm{~kg})$ Lietuvos šèmųjų karvių tèvas buvo bulius Princas 4330, pagal pieno riebumą $(4,43 \pm 0,238 \%)$ išsiskyrè buliaus Šèmio 4483, o pagal baltymingumą $(3,38 \pm 0,048 \%)$ - buliaus Riešutèlio 4402 moteriškos giminès palikuonys.

Fenotipinis karviu produktyvumo ir pieno sudèties rodikliu kintamumas pagal bulius buvo 0,18$8,37 \%$ (9 pav.). Didesnè buliaus ịtaka nustatyta Lietuvos baltnugarių karvių produktyvumui, palyginti

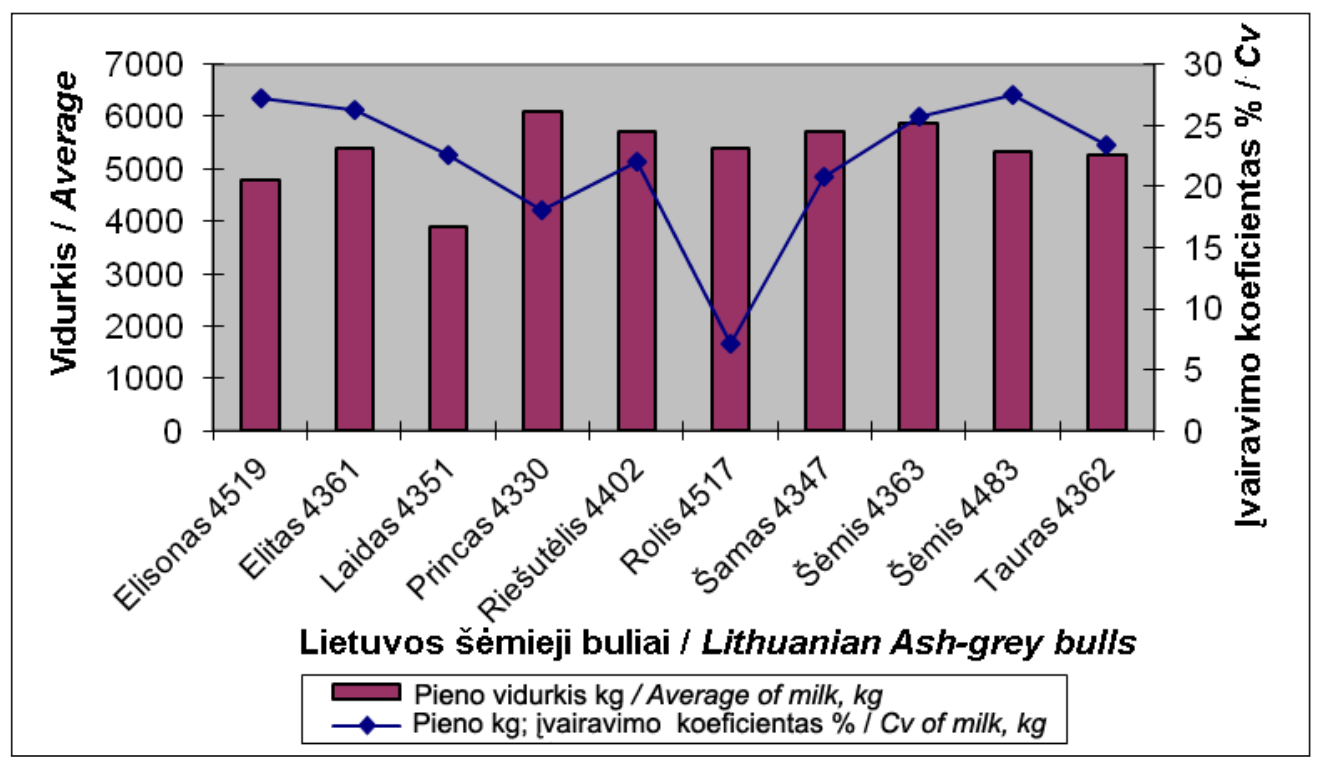

7 pav. Lietuvos šèmųjų karvių pieningumas pagal bulius

Fig. 7. Lithuanian Ash-grey cows' milk, $\mathrm{kg}$ by bulls

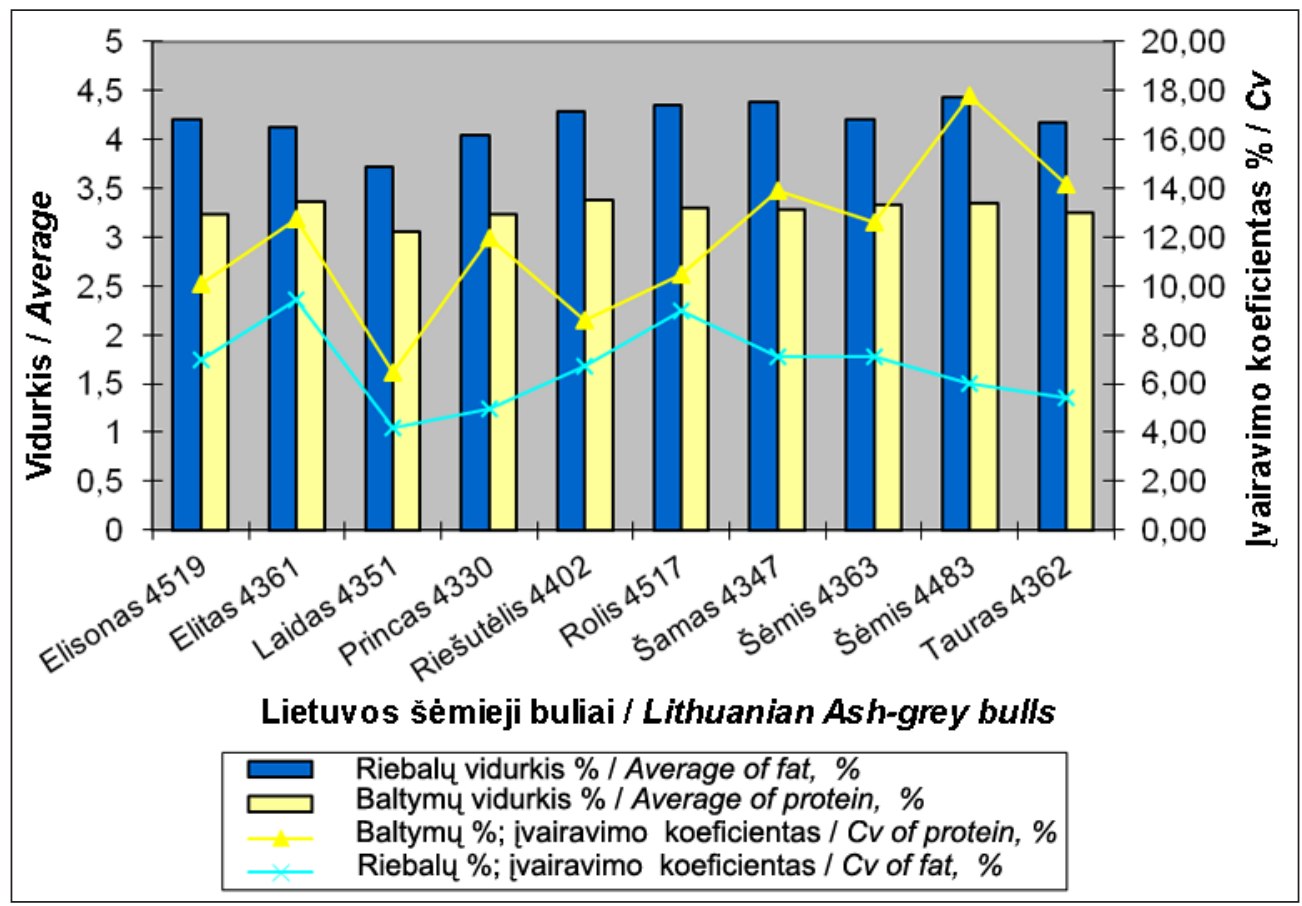

8 pav. Lietuvos šèmųjų karvių pieno sudètis pagal bulius

Fig. 8. Lithuanian Ash-grey cows' milk composition by bulls 


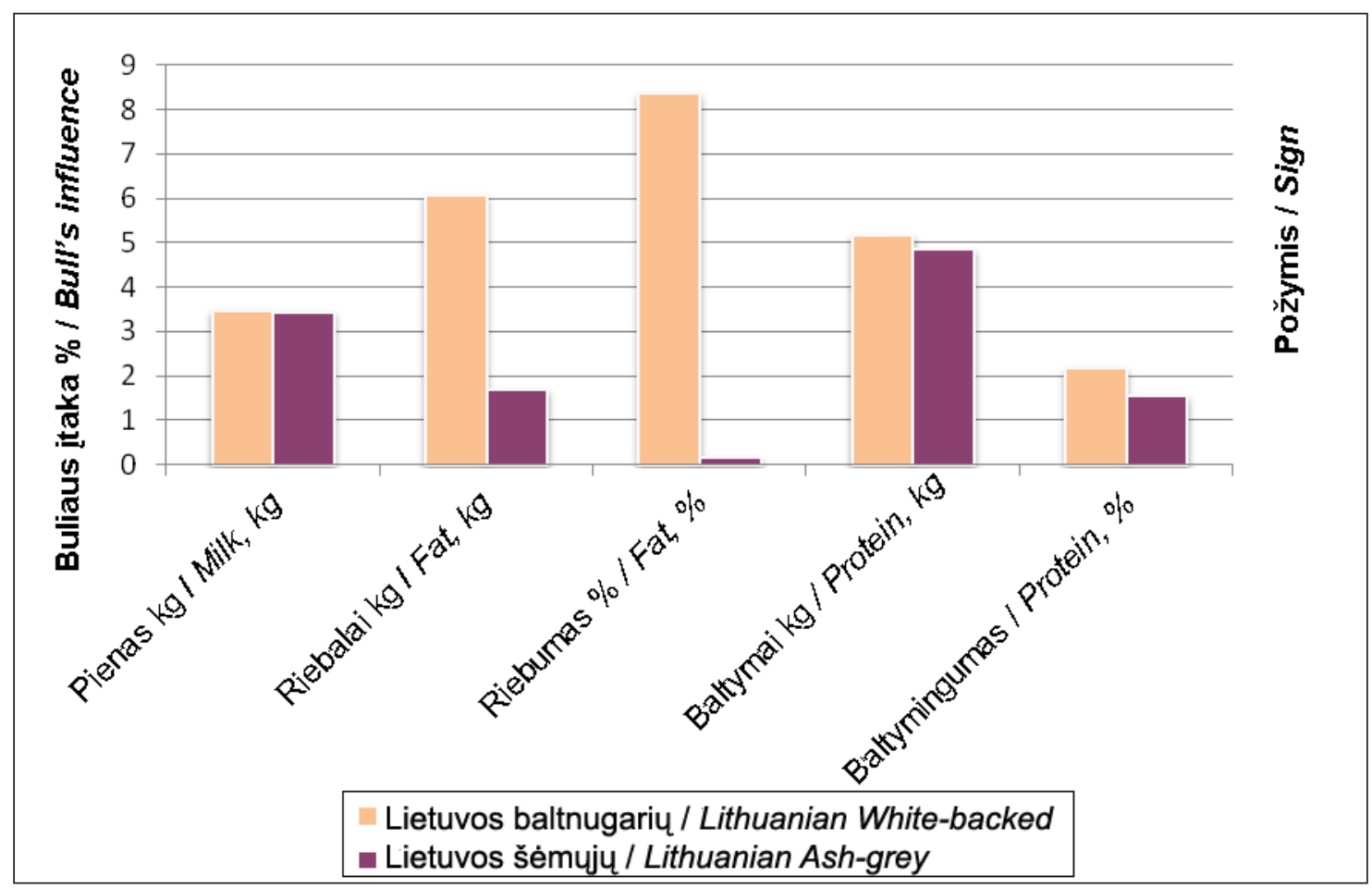

9 pav. Buliaus itaka karvių produktyvumui ir pieno sudèčiai

Fig. 9. Bull's influence on cows' productivity and milk composition

su Lietuvos šèmosiomis. Didžiausios įtakos bulius turëjo Lietuvos baltnugarių karvių pieno riebumui ir baltymų kiekiui, Lietuvos šèmujų - pieno baltymų produkcijai ir primilžiams.

Tiesinès koreliacijos metodu (10 pav.) nustatème Lietuvos baltnugarių ir Lietuvos šèmųjų karvių pieno produkcijos ir sudeties koreliacijos koeficientus.

Abiejų veislių karvių pieningumo koreliacija su pieno riebalų ir baltymų produkcija buvo iš esmès teigiama $(r=0,883-0,952)$. Nustatyta nepageidautina karvių pieningumo mažèjimo tendencija vykdant selekciją pagal pieno baltymingumą $(r=-0,144-$ $0,180)$. Pastebèta, kad didinant karvių pieningumą gali mažèti pieno riebumas $(r=-0,135)$ Lietuvos baltnugarių ir dideti $(r=0,026 ; p<0,05)$ Lietuvos šèmųjų karvių populiacijoje.

E. Nistor su grupe tyrëjų (2009) nustatė panašią (labai aukštą, teigiamą, statistiškai reikšmingą) $(p<0,001)$ koreliaciją tarp Rumunijos dèmètųju karvių (Romanian spotted) pieningumo ir pieno riebalu kiekio $(r=0,9873)$, pieningumo ir pieno baltymų kiekio $(r=0,9568)$, o taip pat tarp pieno riebalų ir baltymų $(r=0,9719)$. V. Juozaitienè su grupe mokslininkų (2004) Lietuvos žalųjų ir žalmargių galvijų populiacijai pagal minètus po- žymius nustatẻ labai aukštą tiesinị statistinị ryšį $(r=0,890-0,967 ; p<0,01)$.

Viena iš svarbiausių pieninių galvijų selekcijos efektyvumo didinimo priemoniu yra veislinès vertès nustatymas naujausiomis gyvulių veislininkystès technologijomis (Christian, 2004; Hayes, Bowman, Chamberlain, Goddard, 2009; VanRaden, Van Tassell, Wiggans, Sonstegard, Schnabel, Taylor, Schenkel, 2009; Harrism, 2010; Su, Gregersen, Lund, 2010; VanRaden, Sullivan, 2010). Lietuvoje, kaip ir daugelyje pasaulio ir Europos Sajungos valstybių, pieninių galvijų genetinių savybių vertinimas yra atliekamas BLUP (geriausia linijinè bešališka prognozè) metodu (Öle, 1990; Lietuvos juodmargių galvijų genealogija, 2002; Valstybès ịmonè Žemès ūkio informacijos ir kaimo verslo centras "Genetinio vertinimo informacine sistema. Genetinio vertinimo modeliai“, 2012). Šiuo metodu galima nustatyti tikrąją gyvulio veislinę vertę atmetant aplinkos sąlygu ịtaką (Grant, 1996; Juozaitienè, 2003; Ibtisam, Zubeir, Owni, Mahomed, 2005).

Nors Lietuvos baltnugarių bulių veislinès vertès, nustatytos BLUP metodu, pagal produktyvumo požymius vidurkis buvo 4,9 balais didesnis nei Lietuvos šèmųjų, tačiau šis skirtumas nebuvo statistiškai reikšmingas (Lentelè). Buliai, kurių 


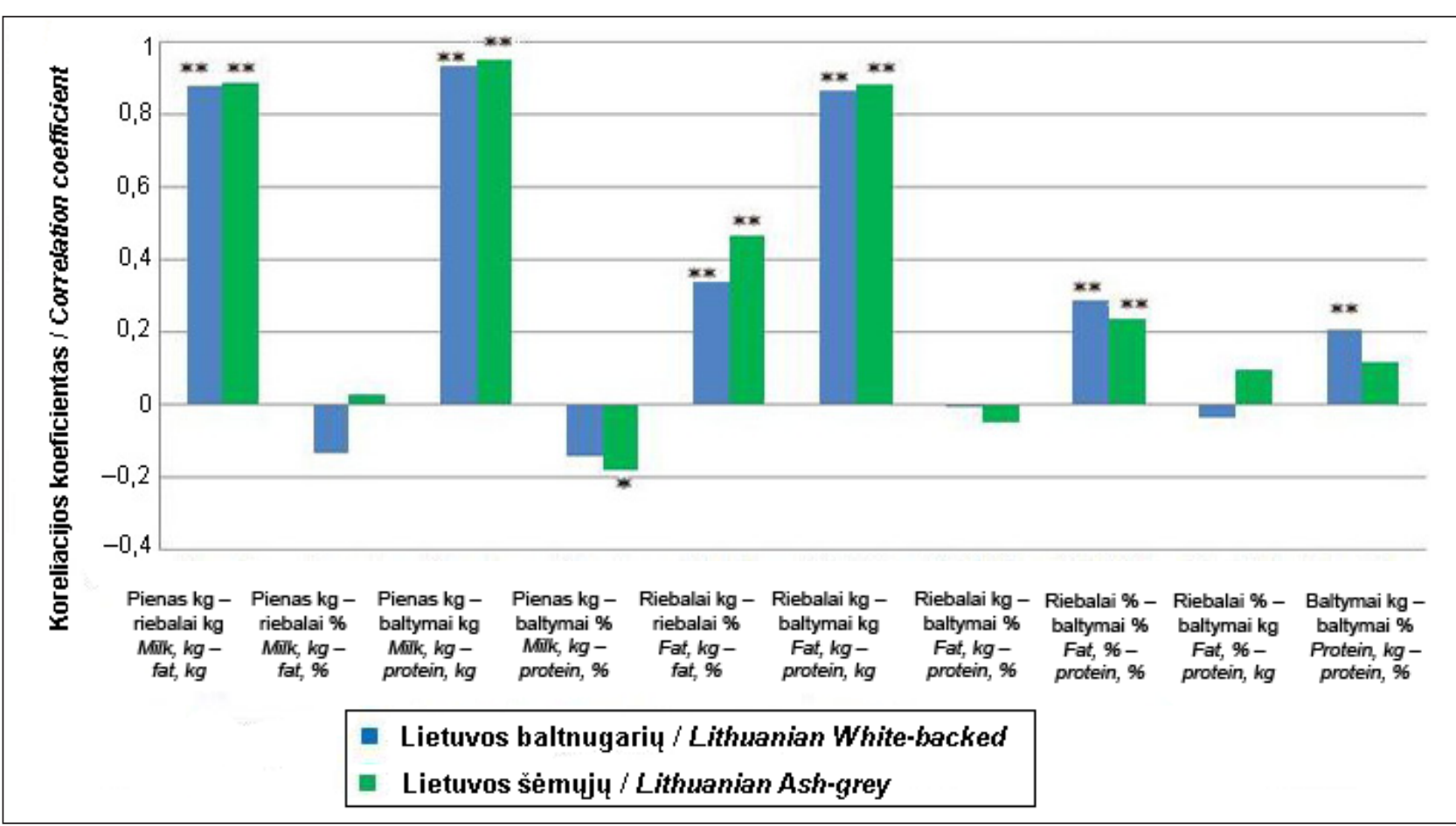

10 pav. Karvių produktyvumo ir pieno sudeties fenotipinès koreliacijos

Fig. 10. Phenotypic correlations between cows' productivity and milk composition

${ }^{\star} \mathrm{p}<0,05 ;{ }^{* *} \mathrm{p}<0,01$

Lentelè. Lietuvos baltnugarių ir šèmųjų bulių veislinės vertės analizè

Table. Analysis of Lithuanian White-backed and Lithuanian Ash-grey bulls' breeding value

\begin{tabular}{|c|c|c|c|c|c|}
\hline $\begin{array}{l}\text { Buliaus vardas ir } \\
\text { numeris } \\
\text { Bull's name and } \\
\text { number }\end{array}$ & $\begin{array}{l}\text { Buliaus } \\
\text { linija } \\
\text { Bull's line }\end{array}$ & $\begin{array}{l}\text { Moteriškos giminès } \\
\text { palikuonių skaičius } \\
\text { Number of daughters }\end{array}$ & \begin{tabular}{|c|} 
Ūkių \\
skaičius \\
Number of \\
farms
\end{tabular} & $\begin{array}{l}\text { Patikimumas } \\
\text { Reliability }\end{array}$ & $\begin{array}{c}\text { Bendras produk- } \\
\text { tyvumo indeksas } \\
\text { Total productivi- } \\
\text { ty index }\end{array}$ \\
\hline \multicolumn{6}{|c|}{ Lietuvos baltnugariai buliai / Lithuanian White-backed bulls } \\
\hline Baltnugaris LJ 4329 & 99 & 141 & 102 & 0,949 & 71 \\
\hline Braižas LJ 4387 & 190 & 124 & 93 & 0,942 & 71 \\
\hline Bukis LJ 4326 & 190 & 157 & 109 & 0,942 & 69 \\
\hline Mènulis LJ 4353 & 932 & 156 & 105 & 0,921 & 75 \\
\hline Rolas LJ 4427 & 931 & 41 & 35 & 0,824 & 70 \\
\hline Taškas LJ 4403 & 920 & 92 & 74 & 0,927 & 78 \\
\hline $\bar{X} \pm m_{x}$ & & $118,5 \pm 18,4$ & $86,3 \pm 11,5$ & $0,918 \pm 0,019$ & $72,3 \pm 1,4$ \\
\hline \multicolumn{6}{|c|}{ Lietuvos šèmieji buliai / Lithuanian Ash-grey bulls } \\
\hline Elisonas LJ 4519 & 932 & 13 & 7 & 0,666 & 56 \\
\hline Elitas LJ 4361 & 932 & 121 & 85 & 0,898 & 61 \\
\hline Laidas LJ 4351 & 99 & 7 & 6 & 0,5 & 74 \\
\hline Princas LJ 4330 & 951 & 97 & 69 & 0,93 & 67 \\
\hline Riešutèlis LJ 4402 & 980 & 97 & 69 & 0,93 & 80 \\
\hline Rolis LJ 4517 & 980 & 97 & 69 & 0,93 & 69 \\
\hline Šamas LJ 4347 & 99 & 105 & 77 & 0,935 & 68 \\
\hline Šèmis LJ 4363 & 99 & 54 & 38 & 0,876 & 68 \\
\hline Šèmis LJ 4483 & 99 & 122 & 85 & 0,939 & 66 \\
\hline Tauras LJ 4362 & 99 & 95 & 67 & 0,898 & 65 \\
\hline $\bar{X} \pm m_{x}$ & & $80,8 \pm 13,2$ & $57,2 \pm 9,4$ & $0,850 \pm 0,047$ & $67,4 \pm 2,1$ \\
\hline$p$ & & 0,127 & 0,075 & 0,208 & 0,069 \\
\hline
\end{tabular}


veislinès vertès indeksas yra $>100$, yra gerintojai, palyginti su bazinių bulių vidurkiu. Analizė parodè, kad Lietuvos baltnugarių ir šèmųjų bulių veislinès vertès indeksai yra $<100$, todèl tokie buliai masinèje selekcijoje nenaudojami, tačiau tai yra mūsų genofondiniai gyvuliai, pasižymintys paveldimųų savybių perdavimo stabilumu.

Paveldimumo koeficientai padeda nuspręsti, kurio požymio gerinimas bus efektyvesnis vykdant selekciją (Cassell, Virginija, 2001; Van Doormaal, Kistemaker, Miglior, 2001).

Nustatème kad mūsų tirtų vietinių galvijų veislių pieningumo paveldimumo koeficientai - nuo 0,34 iki 0,53 , pieno riebalu $-0,36-0,52$, pieno baltymų - 0,38-0,51 - rodo pakankamą efektyviai selekcijai genetinį požymių kintamumą.

\section{IŠVADOS}

1. Nustatème, kad Lietuvos baltnugarès karvè priklausè Olandijos juodmargių veislès bulių $(48,41 \%)$, holšteinų veislès bulių $(29,30 \%)$ ir kitoms linijoms bei giminingoms grupèms (22,29\%). Lietuvos šèmosios karvès priklausè holšteinų veislès $(52,44 \%)$ ir kitoms bulių linijoms bei giminingoms grupèms (47,56\%).

2. Abiejų veislių karvių pieningumo koreliacija su pieno riebalų ir baltymų produkcija buvo iš esmès teigiama $(r=0,883-0,952 ; \mathrm{p}<0,01)$. Pastebèta, kad didinant karvių pieningumą gali mažèti pieno riebumas $(r=-0,135)$ Lietuvos baltnugariu ir didèti $(r=0,026 ; p<0,05)$ Lietuvos šèmųjų karvių populiacijoje. Nustatyta nepageidautina karvių pieningumo mažèjimo tendencija vykdant selekciją pagal pieno baltymingumą $(r=-0,144-0,180)$.

3. Nustatyti pieningumo paveldimumo koeficientai - nuo 0,34 iki 0,53, pieno riebalu - 0,360,52 , pieno baltymų - 0,38-0,51 - rodo pakankamą efektyviai selekcijai genetinị požymių kintamumą.

4. Nors Lietuvos baltnugarių ir šèmujų bulių veislinès vertès, ivertintos BLUP metodu, indeksai yra $<100$, vietiniai baltnugariai ir šèmieji galvijai yra svarbūs mūsų šalies gyvulininkystès raidai, juos reikia dèl unikalių fenotipinių ir genetinių savybių ne tik išsaugoti, bet ir kryptingai gerinti pagal produktyvumą ir pieno sudètí, formuoti ir plèsti veislių genealoginę struktūrą.

Gauta 20130415

Priimta 20130617

\section{LITERATŪRA}

1. Agabriel C., Coulon J. B., Marty G., Bonaiti B. 1993. Changes in fat and protein concentrations in farms with high milk production. Journal of Dairy Science. Vol. 76. No. 3. P. 734-741.

2. Auldist M. J., Coats S., Sutherland B. J., Mayes J. J., Mcdowell G. H., Rogers G. L. 1996. Effects of somatic cell count and stage of lactation on raw milk composition and the yield and quality of cheddar cheese. Journal of Dairy Science. P. 269-280.

3. Bondesan V. 2011. Supporting local breed conservation through the linkage with traditional products. Proceedings of the Workshop on Socio-economic and Cultural Values of Farm Animal Breeds. Aas, Norway: Nordic Genetic Resource Center. P. 30.

4. Cassell B. 2001. Using Heritability For Genetic Improvement.

5. Christian F. 2004. An example of joint evaluation: Germany and Austria. Brown Swiss Bruna 7 Conference. P. 185-189.

6. Groeneveld E., Kovač M., Mielenz N. 2010. VCE User's Guide and Reference Manual Version 6.0. $125 \mathrm{p}$.

7. Grant R. 1996. Maximizing feed intake for maximum milk production. Journal of Dairy Science. P. $1-4$.

8. Grigaliunaite I., Maleviciute J., Värv S., Bennewitz Z., Grislis Z., Fimland E., Meuwissen T. H.E., Miceikiene I., Olsaker I., Viinalass H., Vilkki J., Kantanen J. 2003. Microsatellite analysis for making conservation priorities among North European cattle breeds. Journal of Animal Science. P. 1406-1413.

9. Groeneveld E. 1998. PEST User's Guide. Mariensee: Institut für Tierzucht und Tierverhalten.

10. Groeneveld E. 1998. VCE User's Guide. Mariensee: Institut für Tierzucht und Tierverhalten.

11. GVIS administravimo VGAS procedūros 19 priedas „Lietuvoje veisiamų galvijų veislių ir jų gerinimui naudojamų bulių linijų ir giminingų grupių klasifikatorius".

12. Hayes B. J., Bowman P. J., Chamberlain A. J., Goddard M. E. 2009. Genomic selection in dairy cattle: Progress and challenges. Journal of Dairy Science. Vol. 92. P. 433-443.

13. Harris B. L., Johnson D. L. 2010. Genomic predictions for New Zealand dairy bulls and integration with national genetic evaluation. Journal of Dairy Science. Vol. 93. P. 1243-1252.

14. Ibtisam E. M., Zubeir E. L., El Owni O. A., Mahomed G. E. 2005. Correlation of minerals and enzymes in blood serum and milk of healthy and mastitic cows. Research Journal of Agriculture and Biological Sciences. Vol. 1. No. 1. P. 45-49.

15. Jukna Č., Pauliukas K. 2001. Holšteinų panaudojimas Lietuvos juodmargiu galvijų genetiniam 
potencialui didinti. Žemès ükio mokslai. Nr. 2. P. 54-61.

16. Juozaitienè V., Oberauskas D., Darbutas J., Lavrinovič J. 2004. Lietuvos žaluju ir žalmargiu galviju populiacijos struktūros analizè. $22 \mathrm{p}$.

17. Juozaitienè V. 2003. Atrankos efektyvinimas gerinant juodmargių galvijų populiaciją Lietuvoje. Veterinarija ir zootechnika. T. 22. Nr. 44. P. 18-22.

18. Juškienė V., Šveistienė R., Juška R. 2003. Lietuvos vietinių galvijų ūkinès-biologinès savybès ir priemonès jų genofondo išsaugojimui. Gyvulininkystė: mokslo darbai. T. 42. P. 13.

19. Klaas I. C., Enevoldsen C., Ersbøll A. K., Tölle U. 2005. Cow-related risk factors for milk leakage. Journal of Dairy Science. Vol. 88. P. 128-136.

20. Lietuvos juodmargiu galviju genealogija. 2002. Lietuvos juodmargių galvijų gerintojų asociacija. Marijampole.

21. Lietuvos Respublikos žemés ūkio ministro ịsakymas „Dél galviju genetinio vertinimo pagal produktyvumo, reprodukcijos, ūkinio naudojimo trukmés požymius metodiku ir veisliniu buliu vertinimo komisijos patvirtinimo" 2009 m. lapkričio 5 d. Nr. 3D-834, Vilnius.

22. Malevičiūtė J., Baltrẻnaitė L., Miceikienė I. 2002. Domestic cattle breed diversity in Lithuania. Veterinarija ir zootechnika. Vol. 20(42). P. 87-91.

23. Nistr Gh., Nistor E., Bampidis V., Skapetas B. 2009. Phenotypic correlation between couple of milk production traits in Romanian spotted breed dairy heifers from S. C. Agrosem S. A. Pischia, Timis county. Zootechnics and Biotechnology. Vol. 42(2). P. 317-321.

24. Öle D. 1990. Basic Quantitative Genetic Theory. Uppsala: Swedish University of Agricultural Sciences.

25. Pauliukas K. 1998. Rinktinių juodmargių ir jų F1, F2, F3 ir F4 mišrūnių karvių, turinčių nevienodą Holšteinų kraujo dali, pieno produktyvumas. Veterinarija ir zootechnika. T. 6(28). P. 86-90.

26. Powell R. L., Norman H. D., Sanders A. H. 2003. Progeny testing and selection intensity for Holstein bulls in different countries. Journal of Dairy Science. Vol. 86. No. 10. P. 3386-3393.
27. Sargeant J. M., Leslie K. E., Shoukri M. M., Martin S. W., Lissemore K. D. 1998. Trends in milk component production in dairy herds in Ontario. Journal of Dairy Science. P. 1985-1994.

28. Su G., Guldbrandtsen B., Gregersen V. R., Lund M.S. 2010. Preliminary investigation on reliability of genomic estimated breeding values in the Danish Holstein population. Journal of Dairy Science. Vol. 93. P. 1175-1183.

29. Šveistienė R., Anskienè L. 2011. Lietuvos baltnugariu galviju selekcinio veislinio darbo programa. Lietuvos nykstančių ūkinių gyvūnų augintojų asociacija. P. 1-19.

30. Šveistienè R., Anskienè L. 2011. Lietuvos šèmu galviju selekcinio veislinio darbo programa. Lietuvos nykstančių ūkinių gyvūnų augintojų asociacija. P. 1-19.

31. Urech E., Puhan Z., Schällibaum M. 1999. Changes in milk protein fraction as affected by subclinical mastitis. Journal of Dairy Science. Vol. 82. No. 11. P. 2402-2411.

32. Valstybès ịmonè Žemès ūkio informacijos ir kaimo verslo centras „Genetinio vertinimo informacinè sistema. Genetinio vertinimo modeliai“ [žiūrèta 2013-01-23]. Prieiga per internetą: http://www.vic. $\mathrm{lt} / \mathrm{?mid}=494$

33. Van Doormaal B. J., Kistemaker G., Miglior F. 2001. Establishment of Single National Selection Index for Canada. Proceedings of the Interbull Meeting in Budapest, Hungary. Bulletin No. 27. P. 102-106.

34. VanRaden P. M., Van Tassell C. P., Wiggans G. R., Sonstegard T. S., Schnabel R. D., Taylor J. F., Schenkel F. S. 2009. Reliability of genomic predictions for North American Holstein bulls. Journal of Dairy Science. Vol. 92. P. 16-24.

35. Värv S., Viinalass H., Kaart T., Kantanen J. 2004. Genetic differentiation among commercial and native cattle breeds. Animal Breeding in the Baltics. Proceedings of the 10th Baltic Animal Breeding Conference. Tartu, Estonia. P. 111-114.

36. Zootechniko žinynas. 2007. $107 \mathrm{p}$.

37. Zuchtwertschatzung (German Sire Proofs). Informations-Systeme. Tierhaltung. Ausgabe: Februar 2000. P. 18-21. 
Lina Anskienė, Vida Juozaitienė, Vilius Žiogas,

Aleksandras Muzikevičius, Arūnas Šileika

STATISTIC AND GENETIC STUDIES OF PRODUCTIVITY AND MILK COMPOSITION OF LITHUANIAN WHITE-BACKED AND ASH-GREY COWS

Summary

The aim of the study was to evaluate the genealogy structure, productivity and milk composition of Lithuanian Whitebacked and Lithuanian Ash-grey cows according to bull lines and bulls, as well as selection parameters of these features, and to determine bull breeding value with the linear prediction BLUP method.

Parentage and production data of 711 Lithuanian Whitebacked and 808 Lithuanian Ash-grey cows were used for genetic testing. Statistical data analysis was carried out with PEST (Groeneveld, 1998 ) and VCE (Groeneveld, 1998 ), SPSS statistical package (version 15, SPSS Inc, Chicago, IL).

It was estimated that Lithuanian White-backed cows belong to Dutch black and white breed (48.41 percent), Hol- stein breed bulls (29.30 percent), and other lines and related groups (22.29 percent); Lithuanian Ash-grey cows belong to Holstein breed (52.44 percent), and other bull lines and related groups (47.56 percent).

Phenotypic correlations of milk yield with milk fat and protein production of both cow breeds were highly positive $(\mathrm{p}<0.01)$. The estimated heritability coefficients of milk yield $0.34-0.53$, milk fat $0.36-0.52$, and milk protein $0.38-0.51$ show sufficient genetic variability of features for effective selection.

Although the indices of local bull breeding values, estimated using the BLUP method, are less than 100, local White-backed and Ash-grey cattle are important for our country's livestock development: they must be preserved because of their unique phenotypic and genetic characteristics, and also it is important to improve their productivity and milk composition, to form and expand the breed genealogical structure.

Key words: Lithuanian White-backed, Lithuanian Ashgrey, bull, heritability coefficient, breeding value index 